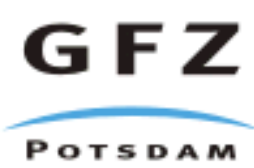

Originally published as:

Kulhánek, O., van Eck, T., John, N., Meyer, K., Wahlström, R. (1983): Spectra of the earthquake sequence February-March, 1981, in south-central Sweden. - Tectonophysics, 93, 3-4, 337-350. 


\title{
SPECTRA OF THE EARTHQUAKE SEQUENCE FEBRUARY-MARCH, 1981, IN SOUTH-CENTRAL SWEDEN
}

\author{
OTA KULHÁNEK, TORILD VAN ECK, NORRIS JOHN, KLAUS MEYER and RUTGER \\ WAHLSTRÖM
}

Seismological Department, Uppsala University, Uppsala (Sweden)

(Received September 23, 1982)

\begin{abstract}
Kulhánek, O., Van Eck, T., John, N., Meyer, K. and Wahlström, R., 1983. Spectra of the earthquake sequence February-March, 1981, in south-central Sweden. In: J. Duda and K. Aki (Fditors), Quantification of Earthquakes. Tectonophysics, 93: 337-350.
\end{abstract}

On February 13, 1981 a relatively strong earthquake occurred in the Lake Vänern region in south-central Sweden. The shock had a magnitude of $M_{\mathrm{L}}=3.3$ and was followed within three weeks by three aftershocks, with magnitudes $0.5 \leq M_{\mathrm{L}} \leq 1.0$. The focal mechanism solution of the main shock indicates reverse faulting with a strike in the N-S or NE-SW direction and a nearly horizontal compressional stress. The aftershocks were too small to yield data for a full mechanism solution, but first motions of P-waves, recorded at two stations, are consistent for the aftershocks. Dynamic source parameters, derived from Pg- and Sg-wave spectra, show similar stress drops for the main shock (2 bar) and the aftershocks $(1 \mathrm{bar})$, while the differences in seismic moment $\left(1.5 \cdot 10^{20}\right.$ resp. $4 \cdot 10^{18}$ dyne $\left.\mathrm{cm}\right)$, fault length $(0.7$ resp. $0.2 \mathrm{~km})$ and relative displacement $(0.15$ resp. $0.03 \mathrm{~cm})$ are significant.

\section{INTRODUCTION}

Sweden represents a region of low seismicity with about ten shallow earthquakes being recorded annually by the Swedish Seismograph Station Network (SSSN) operated by the Seismological Dept., Uppsala (SDU) and comprising six permanent stations (Fig. 1). During the last twenty years, the strongest recorded Swedish earthquake has been assigned a magnitudo $M_{\mathrm{L}}=3.9$. Earthquakes in Sweden are crustal events and take place several thousand kilometres from the nearest plate margin and hence are classified as typical intraplate events .

Earthquakes in Sweden, sometimes followed by series of aftershocks, are of considerable interest from both the seismological and engineering point of view. In recent years, several earthquake sequences have been monitored in southern Sweden.

The relatively strong earthquake near Otterbäcken (Fig. 2), Västergötland, Sweden, on February 13, 1981, followed by a series of aftershocks, provided an opportunity 
to conduct a field survey and a source study linked with a significant but poorly understood zone of seismicity in south-central Sweden. The main shock, $M_{\mathrm{L}}=3.3$, was generally felt up to distances of $20-30 \mathrm{~km}$. The maximum intensity has been

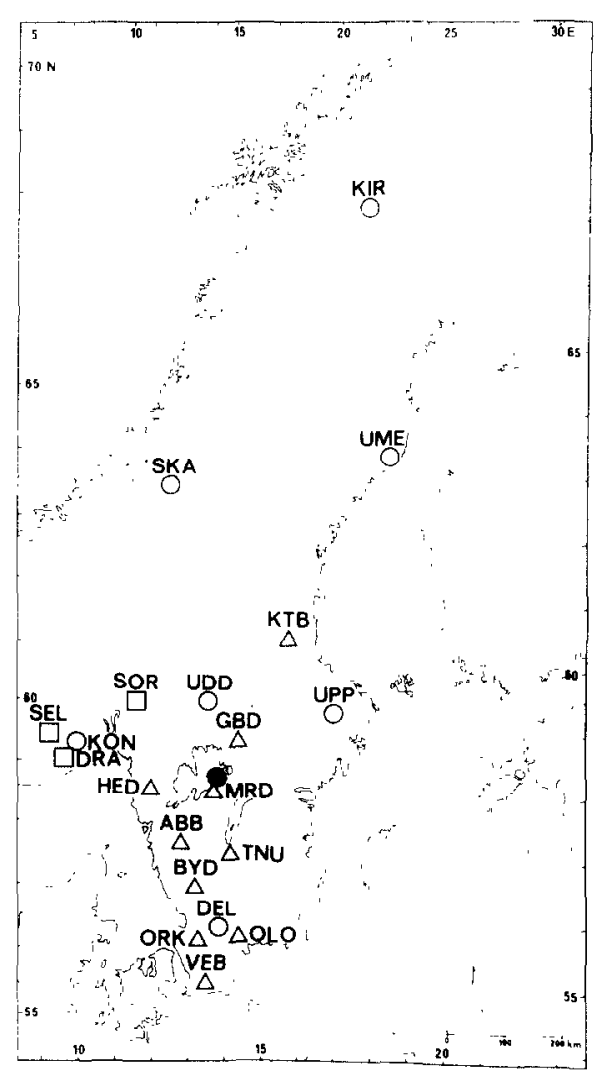

Fig. 1. Distribution of seismograph stations employed in this study. Permanent stations, the SSSN and KON, open circles; SKI stations, open triangles; Southern Norway Seismic Network (SNSN) stations, open squares. Epicentre of the Otterbäcken earthquake of February 13, 1981 is shown as solid circle.

estimated to lie between IV and V. During a one-month field survey several small aftershocks (or presumed aftershocks) from the same source region were detected. Instrumental and macroseismic data of the main shock have been studied and described by Kulhánek et al. (1981a). Some essential results are briefly repeated below.

The work reported here is an attempt to use seismograms from a Swedish regional network to evaluate dynamic source parameters for the three strongest recorded aftershocks $\left(0.5 \leq M_{\mathrm{L}} \leq 1.0\right)$ following the Otterbäcken earthquake. The main objective of this paper is to present the aftershock spectral data and their interpretation in terms of relevant source models. 
The sequence of shocks studied in this paper occurred in the time from February 13 to March 5, 1981 beneath Lake Vänern in south-central Sweden. The sequence

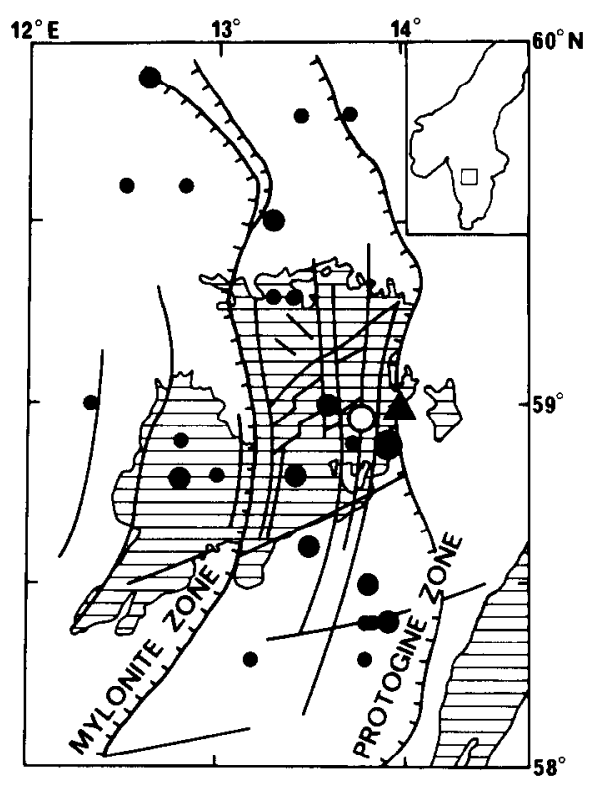

Fig. 2. Schematic diagram of main seismotectonic features in the Lake Vänern region. Solid circles show earthquake epicentres for the years 1967-1981, as determined by the SSSN: $M_{\mathrm{L}}<3$, small circles; $M_{\mathrm{L}} \geq 3$, medium-size circles; February 13, 1981 event, large circle. Open circle denotes epicentral location by the SKI data (see Table I), solid triangle shows the location of the station at Alösund. Heavy lines show main tectonic lineaments (after Hakansson et al., 1978), those with hatchings depict two major faulting belts in southern Sweden, the mylonite zone and the protogine zone.

took place close to two dominating Precambrian tectonic zones in southern Sweden, namely the mylonite and protogine (hyperite) zones (Fig. 2). The two zones are several hundred kilometres long, running approximately in the $\mathrm{N}-\mathrm{S}$ direction, and represent the most significant belts of surface faulting in southern Sweden. Several concepts concerning their origin and evolution have been discussed in the literature. Zeck and Malling (1976) describe a large-scale, low-angle thrusting zone and a consequent E-W direction shortening in the area of Lake Vänern and its northwestern surrounding. They conclude that the thrusting occurred possibly at a destructive plate margin as a result of a collision between two lithospheric plates. However, the area in question shows no signs of oceanic crust, continental-margin sediments or old volcanic activity. Besides, both sides of the protogine zone reveal the same type of rock. Consequently, Gorbatschev (1980), among others, rejects the idea of a 
continental collision and rather advocates an intraplate faulting within the southwestern Baltic Shield.

The area around Lake Vänern, especially to the west of the protogine zone (Fig. 2), shows seismic activity which is large for Swedish conditions. According to Båth $(1979 \mathrm{a})$, the corresponding earthquake hazard is the greatest within Sweden. For instance, for the area bordered by $58^{\circ}-60^{\circ} \mathrm{N}$ and $12^{\circ}-14^{\circ} \mathrm{E}$, there is a $32 \%$ risk of occurrence of an earthquake with magnitude $M_{\mathrm{L}} \geq 3$ within a one-year interval. More detailed record of seismic history of the Vänern region, comprising macroseismic and instrumental data. can be found in catalogues of Kjellén (1910) and Båth (1956, 1979b) and in a paper by Kulhánek and Wahlström (1981). Instrumentally determined epicentres (1967-1981) in, as well as the main tectonic features of, the Lake Vänern region are displayed in Fig. 2.

\section{INSTRUMENTAL DATA AND ANALYSIS}

The epicentre location (Figs. 1 and 2) and origin time for the main shock were computed separately from arrival times at SSSN- and SKI-stations, the latter being operated by the National Defence Research Institute (FOA), Stockholm. Similar results were obtained. The SKI data also yielded a focal depth of $8 \mathrm{~km}$, which is in excellent agreement with macroseismic observations (Kulhánek et al., 1981a). Practically the same epicentre locations were obtained for the main shock and the three aftershocks recorded within three weeks following the main shock. Instrumentally determined focal parameters are summarized in Table I. Relevant information on stations used is listed in Table II and their geographical distribution is shown in Fig. 1. The SKI- and SNSN-stations employ magnetic-tape digital recording with a sampling rate of 60 and 40 samples/s, respectively. Seismograms from KON and the

\section{TABLE I}

The Otterbäcken earthquake sequence, Feb. 13-Mar. 17, 1981

\begin{tabular}{|c|c|c|c|c|c|c|c|}
\hline \multirow[t]{3}{*}{$\begin{array}{l}\text { Event } \\
\text { nr. }\end{array}$} & \multirow[t]{3}{*}{ Date } & \multicolumn{2}{|c|}{$\begin{array}{l}\text { Origin } \\
\text { time } \\
\text { (GMT) }\end{array}$} & \multicolumn{2}{|c|}{$\begin{array}{l}\text { Epicentre * } \\
\text { location }\end{array}$} & \multirow[t]{3}{*}{$\begin{array}{l}\text { Magnitude } * * \\
M_{\mathrm{L}}\end{array}$} & \multirow[t]{3}{*}{ Remarks } \\
\hline & & & & \multirow[t]{2}{*}{${ }^{\circ} \mathrm{N}$} & \multirow[t]{2}{*}{${ }^{\circ} \mathrm{E}$} & & \\
\hline & & $\mathrm{h}$ & $\mathrm{m}$ & & & & \\
\hline 1 & Feb 13 & 06 & 39 & 58.95 & 13.81 & 3.3 & main shock, felt \\
\hline 2 & Feb 13 & 20 & 40 & 58.93 & 13.87 & 0.5 & aftershock \\
\hline 3 & Feb 16 & 16 & 39 & 58.95 & 13.83 & 0.9 & aftershock \\
\hline 4 & Mar 5 & 12 & 09 & 58.95 & 13.83 & 1.0 & aftershock \\
\hline
\end{tabular}

* Times and locations according to FOA.

* Magnitude estimates according to SDU. 
TABLE II

Seismograph stations used in this study *

\begin{tabular}{|c|c|c|c|c|}
\hline \multirow[t]{2}{*}{ Station } & \multirow[t]{2}{*}{ Code } & \multicolumn{2}{|c|}{ Station coordinates } & \multirow{2}{*}{$\begin{array}{l}\text { Epicentral } \\
\text { distance } \\
(\mathrm{km})\end{array}$} \\
\hline & & ${ }^{\circ} \mathrm{N}$ & ${ }^{\circ} \mathrm{E}$ & \\
\hline Mariestad & MRD & 58.6 & 13.7 & 38 \\
\hline Granbergsdal & GBD & 59.5 & 14.6 & 71 \\
\hline Hedekas & HED & 58.7 & 11.8 & 121 \\
\hline Uddeholm & UDD & 60.1 & 13.6 & 128 \\
\hline Abborråsen & ABB & 57.8 & 12.8 & 137 \\
\hline Tenhult & TNU & 57.6 & 14.3 & 148 \\
\hline Sorum & SOR & 60.1 & 11.3 & 191 \\
\hline Broaryd & BYD & 57.1 & 13.2 & 214 \\
\hline Uppsala & UPP & 59.8 & 17.6 & 240 \\
\hline Kongsberg & KON & 59.6 & 9.6 & 251 \\
\hline Drangedal & DRA & 59.1 & 9.1 & 272 \\
\hline Katrineberg & $\mathrm{KTB}$ & 61.1 & 16.3 & 274 \\
\hline Delary & DEL & 56.5 & 13.9 & 276 \\
\hline Olofström & OLO & 56.3 & 14.5 & 297 \\
\hline Örkelljunga & ORK & 56.3 & 13.3 & 301 \\
\hline Seljord & SEL & 59.5 & 8.6 & 305 \\
\hline Veberöd & VEB & 55.6 & 13.5 & 374 \\
\hline Skalstugan & SKA & 63.6 & 12.3 & 523 \\
\hline Umeả & UME & 63.8 & 20.2 & 642 \\
\hline Kiruna & KIR & 67.8 & 20.4 & 1045 \\
\hline
\end{tabular}

* The stations listed belong to the SKI-network except for UPP, KIR, SKA, UME, UDD, DEL, which belong to the SSSN, KON, which is operated by the Seismological Observatory, Bergen University and SOK, DRA, SEL from the SNSN.

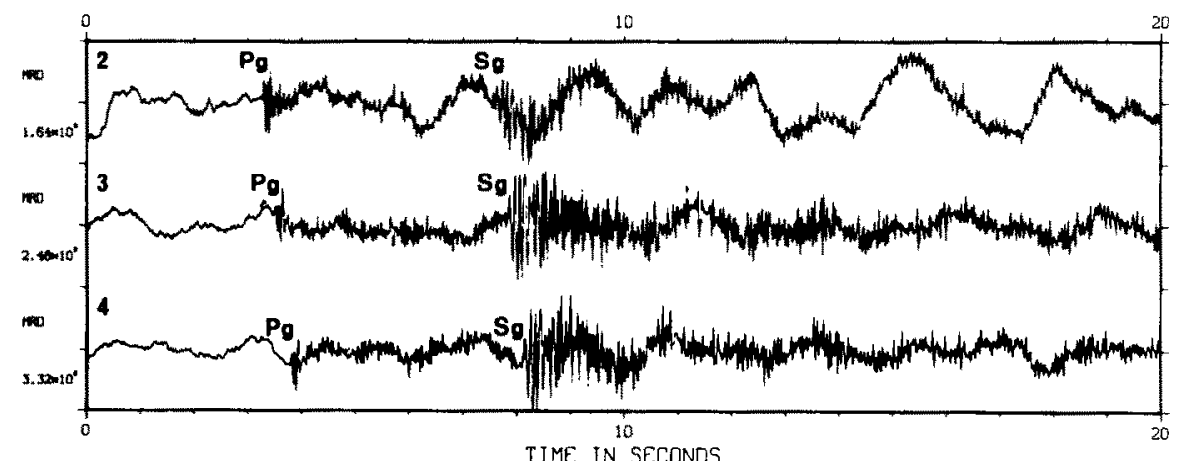

Fig. 3. Portions of MRD vertical-component records of the three aftershocks (Table 1): 2 - February 13, $3=$ February 16, $4=$ March 5 . The magnification of each trace is indicated at left. 
permanent Swedish stations are analog photographic-paper iccords. As an example, seismograms of the three aftershocks recorded at MRD are displayed in Fig. 3.

\section{Focal mechanism}

We have used a simple two-layer crustal model to interpret the propagation paths for Pg- and Pn-phases observed at nine stations to obtain information on the faulting mechanism by the first-motion method. Assuming a double-couple pointsource, the focal mechanism solution shows reverse faulting with a nearly horizontal compressional stress axis oriented $\mathrm{N} 66^{\circ} \mathrm{W}$. Nodal planes with strikes $\mathrm{N} 0^{\circ} \mathrm{E}$ and $\mathrm{S} 50^{\circ} \mathrm{W}$ and with repective dips $62^{\circ}$ and $40^{\circ}$, as displayed in Fig. 4 , fit the observational data. Due to the facts that the strikes agree with the two general trends of tectonic lines in the area (Fig. 2), and that the depth of focus is as great as $8 \mathrm{~km}$, we are not able to discriminate between the nodal planes on the basis of the surface geology.

\section{Dynamic source parameters of the main shock}

Dynamic source parameters of the main shock were determined by making use of displacement spectra observed at 11 stations. Observed spectra are interpreted in terms of the seismic-source model of Brune (1970), i.e. a zero-frequency intercept $\Omega_{0}$, and a high-frequency decay for frequencies above the corner frequency, $f_{0}$, are assumed. We restricted our analysis to $\mathrm{Pg}$ - and $\mathrm{Sg}$-waves recorded by vertical-com-

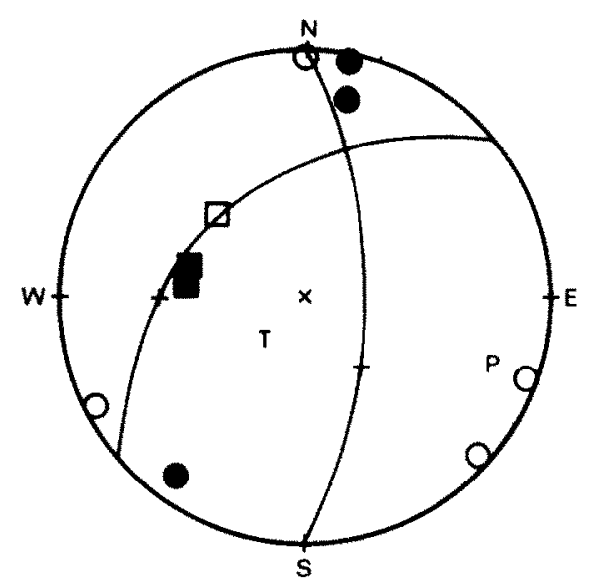

Fig. 4. Fault-plane solution for the Otterbäcken main shock of February 13, 1981, showing the nodal planes and the polarities of the first motions on the lower hemisphere. First motions of $\mathrm{Pg}$ (circles) and $\mathrm{Pn}$ (squares) are shown. Open symbols denote dilatation, solid symbols compression, $P=$ pressure axis, $T=$ tension axis and $+=$ the slip vectors. 
ponent instruments located within the epicentral distance from 38 to $375 \mathrm{~km}$. Selected $\mathrm{Pg}$ - and $\mathrm{Sg}$-waveforms were windowed by using window lengths from 2.1 to $8.5 \mathrm{~s}$. Displacement spectra normalized to a reference distance of $100 \mathrm{~km}, \Omega(f)_{100}$, were obtained after corrections for the instrumental response, the anelastic attenuation effects along the path and the influence of geometrical spreading. Path corrections were performed by employing the usual exponential attenuation law with a frequency independent $Q_{\mathrm{P}}=500$ and $Q_{\mathrm{S}}=1500$, according to Lorenzo (1979) and Båth et al. (1976), respectively. Corrected displacement spectra, $\Omega(f)_{100}$, were then approximated with a constant long-period level, $\Omega_{0}$, and a high-frequency asymptote, $f^{-2}$. On a $\log -\log$ plot, this approximation reduces to two straight lines that intersect at the corner frequency, $f_{0}$. Figure 5 displays several typical corrected Sg-spectra at the reference distance. Dashed lines represent the fit by eye appropriate for the $\Omega_{0}$ and $f_{0}$ spectral parameters. According to the Brune's model, the source dimension is related to $f_{0}$ by:

$r=\frac{0.37 v}{f_{0}}$

In this equation, $r=$ radius of a circular rupture area and $v=$ wave velocity near the source. Zero-frequency intercepts are utilized to estimate the seismic moment, $M_{0}$, following Brune (1970):

$$
M_{0}=\Omega_{0} \frac{4 \pi \rho v^{3} R}{R(\theta, \phi)}
$$

where the density $\rho=2.64 \mathrm{~g} \mathrm{~cm}^{-3}$, the reference hypocentral distance $R=100 \mathrm{~km}$ and $R(\theta, \phi)=$ the radiation pattern coefficient. In the present work, instead of applying a particular radiation correction to each source-station pair, we use the rms
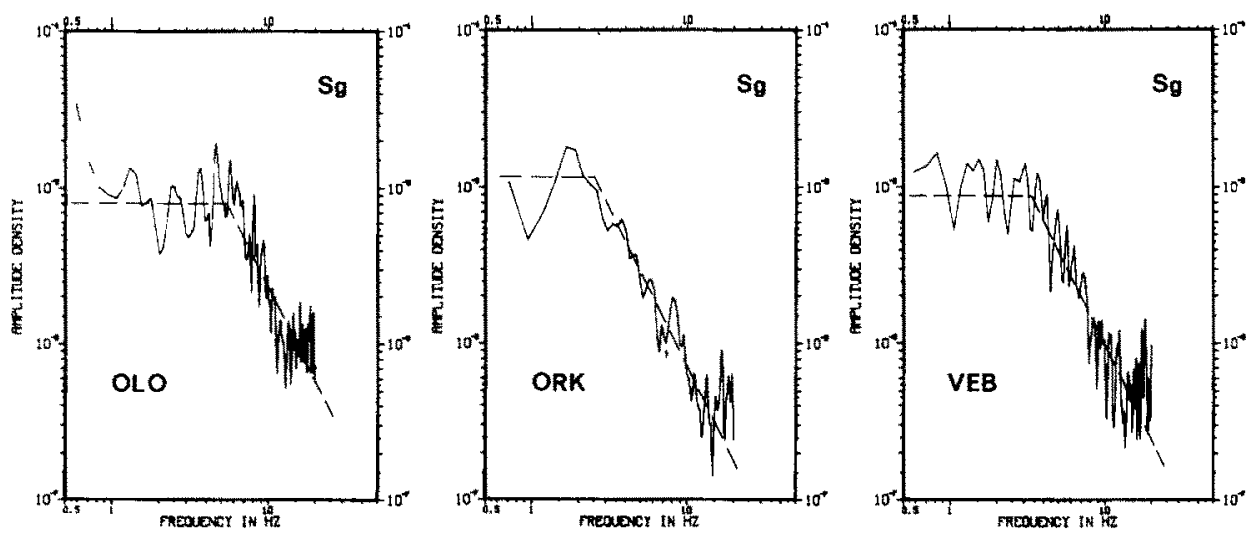

Fig. 5. Main-shock amplitude displacement spectra in $\mathrm{cm}-\mathrm{s}$, equalized to hypocentral distance of $100 \mathrm{~km}$. The idealized spectra are indicated by straight dashed lines. Phases used and relevant station codes (see Table II) are inserted. 
TABLE III

Dynamic source parameters of the Otterbäcken earthquake of February 13, 1981

\begin{tabular}{lllll}
\hline Phase & $\begin{array}{l}M_{0} \\
(\text { dyne-cm) }\end{array}$ & $\begin{array}{l}\Delta o \\
(\text { bar })\end{array}$ & $\begin{array}{l}\bar{u} \\
(\mathrm{~cm})\end{array}$ & $\begin{array}{l}L=2 r \\
(\mathrm{~m})\end{array}$ \\
\hline $\mathrm{Pg}$ & $1.2 \mathrm{E}+20$ & 1 & 0.1 & 700 \\
$\mathrm{Sg}$ & $1.9 \mathrm{E}+20$ & 3 & 0.2 & 600 \\
\hline
\end{tabular}

averages over the focal sphere, namely 0.62 for $\mathrm{S}$-waves and 0.51 for P-waves (Fletcher, 1980).

The stress drop, $\Delta \boldsymbol{\sigma}$, is calculated employing the formula for a circular fault from Brune (1970):

$\Delta \sigma=\frac{7}{16} \frac{M_{0}}{r^{3}}$

Finally, the average displacement, $\bar{u}$, is given by:

$\bar{u}=\frac{M_{0}}{\mu \pi r^{2}}$

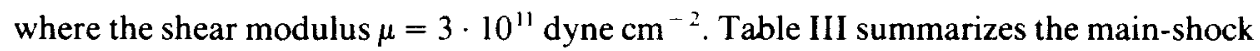
dynamic source parameters, after averaging over all stations. It is emphasized that the stress drops represent average values over the entire fault plane, i.e. that the value obtained from eq. 3 may be significantly less than the stress drop due to the actual fracturing. The average displacement of $0.15 \mathrm{~cm}$ and the fault lenght of $650 \mathrm{~m}$ are both in good agreement with estimates presented by Båth (1980) for Swedish earthquakes with $M_{\mathrm{L}} \doteq 3.3$.

\section{Field survey and aftershock parameters}

On February 13, several hours after the main shock was recorded, we deployed one short-period vertical-component portable seismograph station in the epicentral region at Gullspång. On March 2, the station was moved to Alösund which is located about $12 \mathrm{~km}$ from the epicentre and which provided better noise conditions. Continuous recording was resumed on March 3, with an improvement in dynamic magnification by $12 \mathrm{~dB}$. On March 5, at $13 \mathrm{~h} 09$ and March 7, at $15 \mathrm{~h} 30$ two local events were recorded at Alösund. The event on March 5 was an aftershock to the earthquake of February 13, whereas the event on March 7 is considered as an independent earthquake occurring on the west shore of the lake. From signals recorded at Ålösund (operation ceased on March 17), several additional small events could possibly be interpreted as aftershocks, according to the similarity between 
their wave trains and the record of the aftershock of March 5.

Table I lists source data for the Otterbäcken earthquake sequence within the time period from February 13 to March 17, 1981. The main shock of February 13 was assigned a magnitude $M_{1}=3.3$, calculated from standard SSSN amplitude readings. By correlating the amplitudes of the main shock and the three aftershocks (Table I) measured at six SKI stations, magnitudes were also determined for the aftershocks, even though none of them were recorded by the SSSN.

Seismograms from the three nearest stations (MRD, GBD and HED), at epicentral distances of $38-122 \mathrm{~km}$, were used to determine corresponding aftershock source parameters by making use of eqs. 1-4. Stations at greater distances recorded rather complex $\mathrm{Pg}$ - and $\mathrm{Sg}$-waveforms, seriously contaminated by noise, and were excluded from the analysis. The magnitude, phase used and numerical estimates of source parameters are summarized in Table IV. Pg- and Sg-spectra observed at the three stations typically show a single and well-defined corner frequency. Several aftershock amplitude spectra with their approximation are shown in Figs. 6 and 7. High-frequency amplitude decays, proportional to $f^{-2}$, have been applied throughout the observed spectra even though in most cases an approximation by $f^{-3}$ was equally justified. As can be easily seen from Figs. 6 and 7, our data show no indications of multiple corner frequencies.

As follows from Table IV, the corner frequency of Pg-waves is systematically higher than that of Sg-waves, on the average by a factor of 1.2. This is in excellent agreement with the average value obtained for the main shock from the observations at MRD, GBD and HED (see Kulhánek et al., 1981a). Peppin and Simila (1976) observed that ratios $R=f_{0}(\mathrm{Pg}) / f_{0}(\mathrm{Sg})$, being rather independent of propagation effects, point out conditions at the focus of the earthquake. The frequently used

TABLE IV

Dynamic source parameters of the Otterbäcken aftershock series 1981

\begin{tabular}{|c|c|c|c|c|c|c|c|c|}
\hline Date & $\begin{array}{l}\text { Magnitude, } \\
M_{\mathrm{L}}\end{array}$ & Station & Phase & $\begin{array}{l}f_{0} \\
(\mathrm{~Hz})\end{array}$ & $\begin{array}{l}r \\
(\mathrm{~m})\end{array}$ & $\begin{array}{l}M_{0} \\
\text { (dyne-cm) }\end{array}$ & $\begin{array}{l}\Delta \sigma \\
\text { (bar) }\end{array}$ & $\begin{array}{l}\bar{u} \\
(\mathrm{~cm})\end{array}$ \\
\hline \multirow[t]{4}{*}{ Feb. 13} & 0.5 & MRD & $\mathrm{Pg}$ & 15 & 150 & $2.5 \mathrm{E}+18$ & 0.3 & 0.01 \\
\hline & & MRD & $\mathrm{Sg}$ & 13 & 100 & $1.5 E+18$ & 0.6 & 0.02 \\
\hline & & GBD & $\mathrm{Pg}$ & 15 & 150 & $3.7 E+18$ & 0.4 & 0.02 \\
\hline & & GBD & $\mathrm{Sg}$ & 13 & 100 & $1.3 E+18$ & 0.5 & 0.01 \\
\hline \multirow[t]{4}{*}{ Feb. 16} & 0.9 & MRD & $\mathbf{P g}$ & 15 & 150 & $3.2 E+18$ & 0.4 & 0.01 \\
\hline & & MRD & $\mathrm{Sg}$ & 13 & 100 & $4.2 \mathrm{E}+18$ & 1.7 & 0.04 \\
\hline & & GBD & $\mathrm{Sg}$ & 13 & 100 & $2.9 E+18$ & 1.2 & 0.03 \\
\hline & & HED & $\mathrm{Sg}$ & 13 & 100 & $5.6 \mathrm{E}+18$ & 2.3 & 0.06 \\
\hline \multirow[t]{3}{*}{ Mar. 5} & 1.0 & MRD & $\mathrm{Pg}$ & 14 & 170 & $3.8 \mathrm{E}+18$ & 0.4 & 0.02 \\
\hline & & MRD & $\mathrm{Sg}$ & 12 & 110 & $4.9 E+18$ & 1.6 & 0.04 \\
\hline & & GBD & $\mathrm{Sg}$ & 13 & 100 & $3.2 E+18$ & 1.3 & 0.03 \\
\hline
\end{tabular}



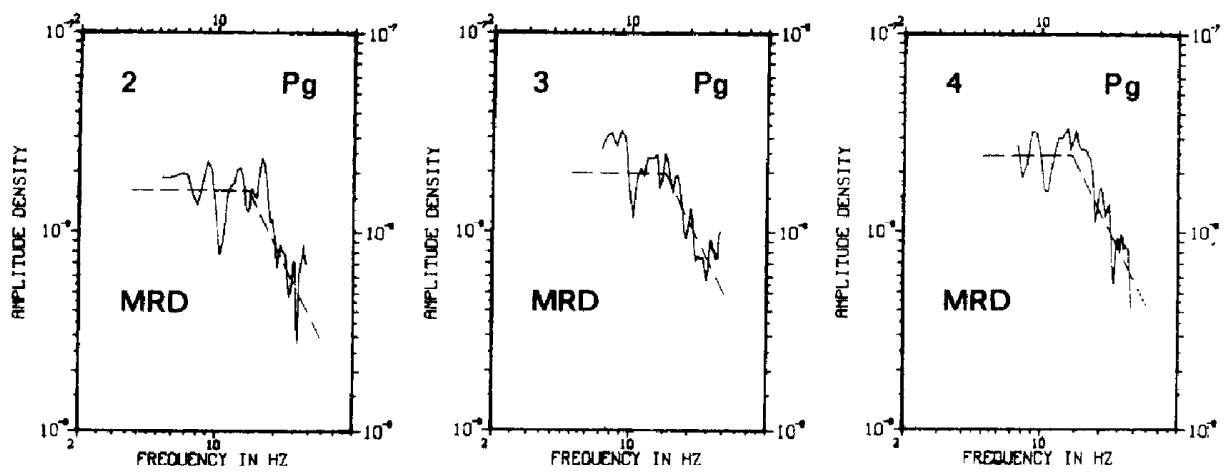

Fig. 6. Amplitude displacement spectra of the three Otterbäcken aftershocks in $\mathrm{cm}-\mathrm{s}$, recorded at MRD and equalized to a common hypocentral distance of $100 \mathrm{~km}$. Relevant event numbers (see Table I) and the phase used are inserted.

Brune's model, which employs an infinite rupture speed on a circular fault and a uniform slip, predicts a ratio $R=1.7$. Provided that the few values of the ratio: $R$ obtained in the present study could be confirmed by more extensive observations, other source models have to be applied for Swedish earthquakes. For example, the model of Madariaga (1976), which considers a circular crack with the slip concentrated near the centre of the crack, may be more appropriate. Also, S-wave corner frequencies derived from Madariaga's model are on the average about 1.8
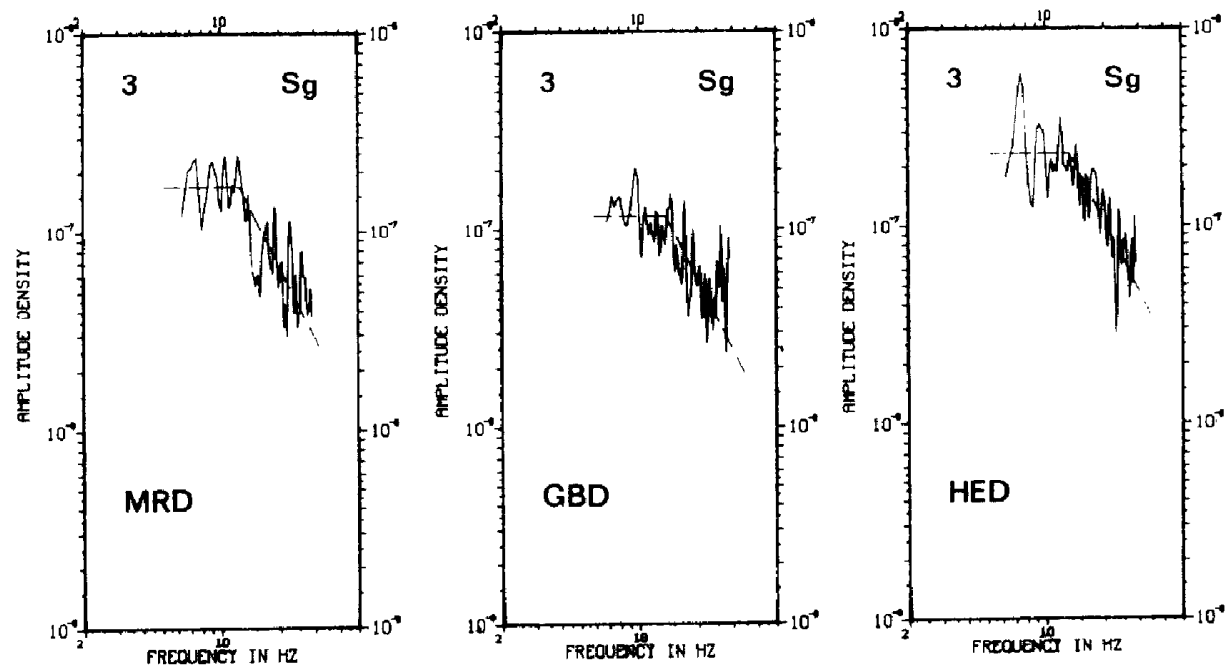

Fig. 7. Amplitude displacement spectra of the Otterbäcken aftershock of February 16, 1981, in $\mathrm{cm}-\mathrm{s}$, equalized to common hypocentral distance of $100 \mathrm{~km}$. Event number (see Table I), phase used and relevant station codes (Table II) are inserted. 
times lower than Brune's corner frequencies, and give average displacements and stress drops about three and five times those resulting from Brune's approximation.

Spectra of the three aftershocks, normalized to the reference distance and recorded at individual stations, show a high degree of similarity. This can be clearly seen in Fig. 6, where Pg aftershock spectra recorded at MRD are displayed. A similar behaviour has been observed for the three $\mathrm{Sg}$ aftershock spectra recorded at MRD and GBD. Although the aftershock data included in this paper stem basically from two stations only (Table IV), one can surmise that the faulting processes, corresponding to the three aftershocks studied, were similar. This assumption is further supported by consistent first-motion polarities of the aftershocks observed at MRD and GBD. The spectral similarities also signify the proximity of the three foci, On the other hand, GBD-records reveal clearly that the main-shock first-motion is not consistent with that of the aftershocks, indicating the possibility of different planes of faulting.

There is a general tendency for the source size and the stress drop to increase with increasing $M_{\mathrm{L}}$ (Randall, 1973, Thatcher and Hanks, 1973). However, our data demonstrate no simple relation between these parameters. The corner frequencies and deduced fault dimensions remain essentially constant for the three aftershocks (Table IV) and the stress drop of the main shock $\left(M_{\mathrm{L}}=3.3\right)$ compares favourably with that of the two larger aftershocks $\left(M_{\mathrm{L}}=0.9,1.0\right)$. As follows from our investigations, the fault radii increase only by a factor of 2 for an almost 100 -fold increase in seismic moment. It is likely, that this behaviour is due not only to uncertainties in our spectral estimates but also to intrinsic differences (focal mechanism, rupture velocity) among the sources themselves.

In general, our source parameters of the main shock as well as of the three aftershocks are consistent with values predicted by Randall (1973) or Gibowicz (1975) and with observations reported for small earthquakes (e.g., Thatcher and Hanks, 1973; Masuda and Takagi, 1978; Marion and Long, 1980). Several authors (Chouet et al., 1978; Rautian et al., 1978) observed almost constant corner frequencies for small earthquakes within a rather wide interval of seismic moments or magnitudes. From relations (1) and (3) it is seen that this implies an increase in stress drop with increasing seismic moment. However, for events larger than $M_{0} \doteq$ $10^{20}$ dyne $\mathrm{cm}$ and/or $M_{\mathrm{L}} \doteq 3.0$, corner frequencies were found to decrease with increasing seismic moment so that stress drop became independent of earthquake size. These observations are in good agreement with the present results.

\section{DISCUSSION}

Stresses released during earthquakes in Fennoscandia may be due to relative movements of lithospheric plates (Richardson et al., 1979; Solomon et al., 1980), the observed differential post-glacial uplift (Båth, 1954; Mörner, 1979) or possibly also other mechanisms. Hitherto, more observational details are available merely for two 
earthquake sequences in southern Sweden, namely for the sequence discussed in the present paper and for that of the Bergshamra earthquake, $M_{1}=3.2$, in 1979 (Kulhánek et al.. 1981b). In both cases, P-wave first-motion analysis reveals reverse faulting on $\mathrm{N}-\mathrm{S}$ to $\mathrm{NE}-\mathrm{SW}$ striking nodal planes. Principal compressional stress axes are in both cases nearly horizontal with a NW-SE orientation which agrees well with in -situ measurements (Hast, 1969, Stephansson and Carlsson, 1976) and with the dominant orientation obtained from five microearthquakes in central western Sweden, as presented by Slunga (1981). The consistency in orientations of compressional axes, being in good agreement with orientations predicted by models of Richardson et al. (1979), suggests uniform stress conditions throughout southern Sweden. This consistency is obviously a strong argument in favour of considering tectonic forces, associated with motions of continental plates, as main causes of earthquakes in the region. Nevertheless, it is well known that displacements due to earthquakes occur on pre-existing zones of weakness rather than on new slip-planes in previously not fractured rock blocks. Assuming that the faults were created in tectonic environments different from the present, the inferred stress axes may differ significantly from the current tectonic stress field in the region. On the other hand, if pre-existing faults are randomly oriented it is likely that the effect of these faults will be small in large areas with consistent fault-plane solutions.

Considering the post-glacial uplift as cause of Swedish earthquakes, investigations carried out in eastern Canada are of particular importance. The Canadian Shield has a seismicity, a topography, the bedrock and the history of glaciation and deglaciation similar to that of the Baltic Shield. Features of post-glacial faulting in eastern Canada have been discussed in greater detail by $\Lambda$ dams (1981) and Hasegawa and Adams (1981). These faults occur in a geologically stable region, are almost always reverse with little or no strike-slip displacement and have small throws of the order of centimeters. These characteristics evidently compare favourably with faulting deduced from the recent Bergshamra and Otterbäcken sequences.

Seismological and other data studied so far do not provide an unambiguous explanation of the origin of stresses released through earthquakes which take place in the crust beneath southern Sweden. Neither plate tectonics nor post-glacial uplift can be a priori excluded. Isolated earthquakes may not reflect dominating stresses acting within the region. Heterogeneities in topography or loading history may be the true causes of these earthquakes (Richardson et al., 1979). More events have to be studied to understand the seismotectonic regime of the area.

\section{ACKNOWLEDGEMENTS}

This study has been carried out at the Seismological Department, Uppsala University, Sweden. The work was supported jointly by the Swedish Nuclear Fuel Supply Co. and by the Swedish Natural Sciences Research Council. Magnetic tape records from the SKI network were kindly supplied by our colleagues in Stockholm. 


\section{REFERENCES}

Adams, J., 1981. Postglacial Faulting: a Literature Survey of Occurrences in Eastern Canada and Comparable Glaciated Areas. Atomic Energy of Canada Limited, TR-142, 63 pp.

Båth, M., 1954. Seismicity of Fennoscandia and related problems. Gerl. Beitr. Geophys., 63: 173-206.

Båth, M., 1956. An earthquake catalogue for Fennoscandia for the years 1981-1950. Sver. Geol. Unders., Årsb., C545 (50): 52 pp.

Båth, M., 1979a. Seismic risk in Fennoscandia. Tectonophysics, 57: 285-295.

Båth, M., 1979b. Earthquakes in Sweden 1951-1976. Sveriges Geol., Unders., Årsb., C750 (72): 79 pp.

Båth, M., 1980. Fracture risk estimation for Swedish earthquakes. Tectonophysics, 61: T15-T22.

Båth, M., Kulhánek, O., Van Eck, T. and Wahlström, R., 1976. Engineering Analysis of Ground Motion in Sweden: Fourier and Reponse Spectra, Attenuation, Regional Magnitude, Energy, Acceleration. Seismol. Inst., Uppsala, Rep. 5-76, 48 pp.

Brune, J.N., 1970. Tectonic stress and the spectra of seismic shear waves from earthquakes. J. Geophys. Res., 75: 4997-5009.

Chouet, B., Aki, K. and T'sujiura, M., 1978. Regional variation of the scaling law of earthquake source spectrum. Bull. Seismol. Soc. Am., 68: 49-80.

Fletcher, J.B., 1980. Spectra from high-dynamic range digital recordings of Oroville, California aftershocks and their source parameters. Bull. Seismol. Soc. Am., 70: 735-755.

Gibowicz, S.J., 1975. Variation of source properties: The Inangahua, New Zealand, aftershocks of 1968. Bull. Seismol. Soc. Am., 65: 261-276.

Gorbatschev, R., 1980. The Precambrian development of southern Sweden. Geol. Fören. Stockholm Förh., 102: 129-136.

Håkansson, L., Fredén, C., Lindh, A., Ronge, B. and Stigh, J., 1978. Vänerns Morfometri och Morfologi. Liber Förlag, 97 pp.

Hasegawa, H.S. and Adams, J., 1981. Crustal Stresses and Seismotectonics in Eastern Canada. Earth Phys. Branch Energy, Mines and Resources Canada, $61 \mathrm{pp}$.

Hast, N., 1969. The state of stress in the upper part of the earth's crust. Tectonophysics, 8: 169-211.

Kjellén, R., 1910. Sveriges jordskalf. Göteborǵs Högsk. Årsskr., 15: 211 pp.

Kulhánek, O. and Wahlström, R., 1981. Macroseismic observations in Sweden, 1977-1979. Sveriges Geol. Unders., Årsb., C776(74), 13 pp.

Kulhánek, O., Van Eck, T., John, N., Meyer, K. and Wahlström, R., 1981a. The Otterbäcken. Sweden, earthquake of February 13, 1981. Seismol. Sect., Uppsala, Tech. Rep., 42 pp.

Kulhánek, O., John, N., Meyer, K., Van Eck, T. and Wahiström, R., 1981b. Source parameters and seismotectonic implications of the recent Bergshamra. Sweden, earthquake. Earth Evolution Sci., 1: $66-70$.

Lorenzo, R., 1979. Attenuation of Short-Period Pg and Pn in Sweden. Seismol. Inst., Uppsala, Rep. 6-79, $21 \mathrm{pp}$.

Madariaga, R., 1976. Dynamics of an expanding circular fault. Bull. Seismol. Soc. Am., 66: 639-666.

Marion, G.E. and Long, L.T., 1980. Microearthquake spectra in the southeastern United States. Bull. Seismol. Soc. Am., 70: 1037-1054.

Masuda, T. and Takagi, A., 1978. Source parameter estimates for small earthquakes. Sci. Rep. Tôhoku Univ., Ser. 5, Geophys., 25: 39-54.

Mörner, N.A., 1979. Earth movements in Sweden, 20.000 BP to 20.000 AP. Geol. Fören. Stockholm Förh., 100: 279-286.

Peppin, W.A. and Simila, G.W., 1976. P- and SV-wave corner frequencies over low-loss paths: a discriminant for earthquake source theories? J. Phys. Earth, 24: 177-188.

Randall, M.J. 1973. The spectral theory of seismic sources. Bull. Seismol. Soc. Am., 63: 1133-1144.

Rautian, T.G., Khalturin, V.I., Martynov, V.G. and Molnar, P., 1978. Preliminary analysis of the spectral 
content of $\mathrm{P}$ and $\mathrm{S}$ waves from local earthquakes in the Garm T- ajjtkistan region. Bull. Seismol. Soc. Am., 68: 949-971.

Richardson, R.M., Solomon, S.C. and Sileep, N.H., 1979. Tectonic stress in the plates. Rev. Geophys. Space Phys.. 17: 981-10! 9 .

Slunga, R., 1981. Foc.il mechanisms of earthquakes in Scandinavia -... A review. Earth Evolution Sci, 1: $61-65$.

Solomon. S.G., Richardson, R.M. and Berghtah, E.A., 1980. Tectonic stress: models and magnitudes. J. Geophys. Res., 85: 6086-6092.

Stephansson, O. and Carlsson, H., 1976. Seismotectonic Analysis of Fennoscandia: A Study for Seismic Risk Analysis for Forsmark. Forsmark Power Plant. Block 3, Appendix H, part 2, Swedish Power Board, 84 pp.

Thatcher, W. and Hanks. T.C., 1973. Source parameters of southern California earthquakes. J. Geophys. Res., 78: 8547-8576.

Zeck, H.P. and Malling, S., 1976. A major global suture in the Precambrian basement of SW Sweden? Tectonophysics. 31: T35-T40. 